\title{
Relation between Learning Disabilities and Socioemotional Skills in Children and Adolescents: A Systematic Review
}

\author{
Gabriela Narváez-Olmedo ${ }^{1, *}$, Josefina Sala-Roca ${ }^{2}$, Aida Urrea-Monclús ${ }^{2}$ \\ ${ }^{1}$ Faculty of Education, Science and Technology, Técnica del Norte University,Ibarra, Ecuador \\ ${ }^{2}$ Theory of Education and Social Pedagogy Department, Faculty of Sciences Education, Autonomous University of Barcelona, Spain
}

Received August 12, 2020; Revised December 22, 2020; Accepted January 25, 2021

\section{Cite This Paper in the following Citation Styles}

(a): [1] Gabriela Narváez-Olmedo, Josefina Sala-Roca, Aida Urrea-Monclús, "Relation between Learning Disabilities and Socioemotional Skills in Children and Adolescents: A Systematic Review," Universal Journal of Educational Research, Vol. 9, No. 4, pp. 819 - 830, 2021. DOI: 10.13189/ujer.2021.090415.

(b): Gabriela Narváez-Olmedo, Josefina Sala-Roca, Aida Urrea-Monclús (2021). Relation between Learning Disabilities and Socioemotional Skills in Children and Adolescents: A Systematic Review. Universal Journal of Educational Research, 9(4), 819 - 830. DOI: 10.13189/ujer.2021.090415.

Copyright $\mathrm{C} 2021$ by authors, all rights reserved. Authors agree that this article remains permanently open access under the terms of the Creative Commons Attribution License 4.0 International License

\begin{abstract}
The relationship of learning disabilities with social-emotional competencies has been a subject of extensive study in previous decades. It has been possible to identify that the decrease in socio-emotional competencies can hinder the development of the academic progress of students with learning disabilities. However, at present, the researches that address this issue have been comparatively scarce, and at certain points, it has been identified that they could be improved in future studies. Within the framework of this idea, this systematic and methodical review focuses on describing empirical studies that relate these two variables and, additionally, on analyzing and scrutinizing the results that most recent research have reached. This review has taken as reference databases such as Eric, Scopus, and PsycInfo, in the period from 2013 to 2018. The results show that, although most of the assessed studies acknowledge that children and adolescents with learning disabilities have lower socio-emotional competencies, it has not been possible to specify the causes of this relationship, besides, the various instruments used and the variety of theoretical explanations of the two variables studied, resulting in a lack of synchronicity in the explanation of these results. That is why it is necessary to deepen and expand the subject by manipulating other variables and fluctuations that could have an impact on this relationship, like sex, the type of disabilities, age, and the cultural context in which the students operate, among
\end{abstract}

others. The question of continuing with similar research to be carried out has been risen to modify the limitations discovered in terms of the instruments used, the variety of types of socio-emotional competences, the lack of specificity of learning disabilities, and especially in the systematic and longitudinal methodology which in turn provides the identification of more specific characteristics regarding the causal relationship of learning disabilities and socio-emotional competences.

Keywords Learning Disabilities, Socio-Emotional Skills, Systematic Review, Children, Adolescents

\section{Introduction}

Learning disabilities (LD) have become one of the most frequent challenges for teachers, the family, and for the students who have them. LD or also known as specific learning disabilities (SLD) are a group of disorders that occur mainly in speech, listening, reading, writing, mathematics; difficulties in reasoning, self-expression, social perception, motor functions, and acquisition and performance of organizational skills [38]. According to the Diagnostic and Statistical Manual of Mental Disorders APA V [2], people with SLD understand tasks in one or 
more specific domains of learning, such as reading, writing, and mathematics; even when they do not reach levels of intellectual deficiency. LDs are also defined as a consequence of a dysfunction of the central nervous system that influences the individual's ability to interpret and connect information, triggering an interruption in the normal course of the acquisition of learning skills [22].

The existence of several definitions and even several terms used to name and explain this type of disabilities, has generated discrepancies in understanding and, therefore, in the professional approach [13]. However, even having this theoretical diversity, the visualization of the problems that are triggered by this difficulty is evident at all levels. Students with LD can be vulnerable to experiences of stigmatization, which in turn are associated with negative academic and emotional effects [10]. It has also been found that one of the characteristics of children with LD is impulsive behavior, their main problem being lack of premeditation, lack of perseverance, and urgency [1]. Research has also been carried out in adults with a history of LD in childhood, where it was found that compared to their peers without LD, subjects with this problem had a greater tendency to contract mental health problems, not to obtain a degree from compulsory education or being unemployed for a longer time [4].

Without a doubt, one of the greatest difficulties encountered in students with LD is the vulnerability they have to be socially excluded. This can happen because their classmates and teachers give less positive evaluations about them, as a consequence of a general lack of knowledge about these difficulties [28]. Another reason for this exclusion has been explained by the inadequate management of socio-emotional competencies (SEC) of students with LD $[25,27]$, thus becoming a topic of investigative relevance. To determine an accurate definition of what SEC is, it is important to take into account that this idea evolves from the condition known as "emotional intelligence", explained by authors such as Mayer and Salovey [24] and Goleman [14], as a series of cognitive components together with the ability to reflect on emotions. And, on the other hand, the term "competence" is known as the expertise of mastering a set of knowledge, attitudes, and skills for the specific exercise of a function [31]. In this way, SEC is the set of knowledge, attitudes, and skills to understand, express, and appropriately regulate one's own emotions and those of others [7].

The development of SEC in students with LD is a topic that has been approached from different angles and for some time $[17,34,41]$. The results of these studies have reached various conclusions, which show that children and adolescents who have LD have lower SEC [5, 22, 29].

The emphasis of this article is on the methodological aspects and the main findings of related studies, that is, its guiding question can be established as what methodological characteristics and results have recent studies and empirical research about the underlying relationship between socio-emotional skills and learning disabilities? Consequently, to answer this question, this study has main objectives: 1) To describe empirical researches that relate socio-emotional competencies and learning disabilities in children and adolescents, and 2) Analyze the results that these researches have reached.

This work aims to contribute to the understanding of the relationship between LD and SEC, through the analysis of studies on the subject in the last six years, to provide an overview of these studies. In the future, this will allow more empirical research in the area with different approaches and methodologies that could provide possible solutions to the difficulties presented by the studied population.

\section{Methodology}

This systematic review was carried out following a specific procedure and guidelines [21,30].

\section{Search and selection of articles}

The search and selection of works were carried out in 5 phases: phase of identification, selection, eligibility, inclusion and exclusion, and evaluation of bias (Figure 1).

1. Identification phase: A search was carried out in the bibliographic databases Eric, Scopus, and PsycInfo, using the following keywords: (" "socioemotional compete *" OR "social skill *" OR "social compete *" OR "emotional compete * "OR" emotional skill * "OR" emotional intelligen * ") AND (" learning disabilit * "OR" learning difficult * "OR" learning disorder *")). The works should have been published between 2013 and 2018, in English or Spanish, however, no results were found in Spanish.

2. Selection phase: The search detected a total of 221 articles that included the keywords among the three databases. Using the Mendeley bibliographic manager, duplicate articles were eliminated, leaving 149 articles.

3. Eligibility phase: Reading the title and the abstract allowed eliminating the articles that did not address the relationship between the two study variables. After this process, 56 articles remained.

4. Bias evaluation phase: To reduce the bias of this systematic review, an external expert was asked to carry out the same process to confirm the data obtained from the first 3 phases.

5. Inclusion and exclusion phase: The papers were read to confirm whether they met the inclusion criteria. Only empirical studies that related the variable "socio-emotional competences" with the variable "learning disabilities" were included. In this review, the samples of interest were children and adolescents. 
However, a study with 25-year-old students was also included to meet the rest of the criteria. Another characteristic that the sample had to fulfill is to be diagnosed with some type of LD; even so, it should not have comorbidity with other diagnoses. Three articles that spoke about "non-verbal learning disability" (NVLD) were excluded because this disability had additional characteristics to those of a diagnosis of LD.
Another inclusion criteria consider that there should be evidence of the evaluation of the SEC in the sample. Furthermore, articles that did not have access to the full text and those that corresponded to systematic reviews or meta-analyzes were excluded.

After this process, the 21 articles used in this review were confirmed.

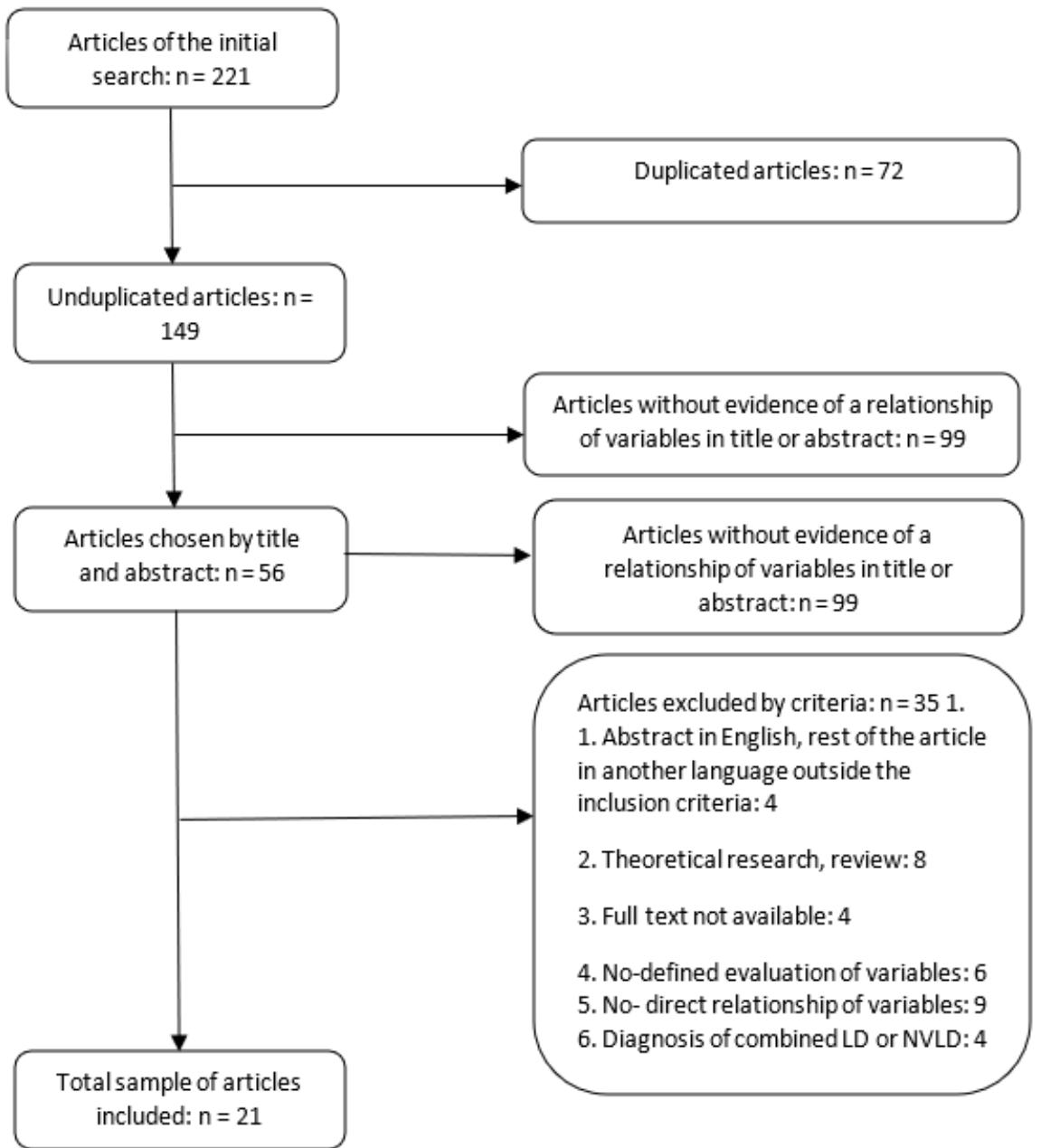

Figure 1. Search flowchart and article selection 


\section{Own elaboration}

\section{Systematization of the information and analysis procedure}

Once the database of the 21 articles to be analyzed was ready, the classification of the information proceeded. A matrix was developed with the most relevant information, like the objective, the methodological approach and design, the type of sample, the type of LD, the instruments used to detect LD, the types of SEC, the instruments used to detect the SEC, and the results obtained.

To synthesize the information, the LD section was categorized in two crucial aspects. On one hand, the diagnostic criteria (general learning disability or specific disability in writing, reading, or mathematics) were examined, and on the other, it was analyzed whether this diagnosis had been made before or during the study.

\section{Results}

\section{Studies overview}

Table 1 summarizes the objectives, the methodology, the type of sample, the means for obtaining the diagnosis of LD, and the instruments applied for the evaluation of SEC. However, in most cases, it can be said that the instruments used in samples of boys and girls inquire about the perception of parents or teachers, while in the samples of adolescents, self-perception instruments of SEC are preferred and only the three longitudinal researches specify the devices that diagnose LD during researches.

Likewise, it was found that most of the studies [2, 5, 6, 7, $10,11,13,14,15,16,17,18,20]$ approach their research from a population with a general interpretation of LD. It means that it is specifically undetailed in which area or fields of learning children/adolescents have difficulties, except for six studies that do $[3,4,8,12,19,21]$ and a pair combining populations with both general and specific diagnoses [1,9]. However, most of these particular diagnoses are reflected in the description of the sample but not in the results.

\section{Own elaboration (The complete references are in table 2 and 3)}

\section{Analysis of results on the relationship between $L D$ and SEC} (Table 2)

Students with LD have low levels of receptive and written communication and general adaptive behavior [1], in preschool-age; they also have difficulties in levels of adaptation and social skills [3]. Apart from having lower social skills, they also have lower academic achievement and greater feelings of loneliness [7]. They are perceived as less independent and have difficulties in waiting in turns, in learning in groups, and in making decisions during class activities [10]. However, one study determined that children with LD do not have significant effects on social or antisocial behaviors [6], and another that their sample with LD has better SEC than the rest of the boys and girls with different Special Education Needs (SEN) [8].

Both adolescents and children with LD demonstrate low levels of SEC. They are perceived as less socially efficient and their peers without LD see them as rejected students [2], with greater interpersonal difficulties when speaking in public, in relationships with family and friends, and with lower self-concept in the academic and social area [4] and also with indicators of social anxiety [5]. Finally, the research found that the self-concept of emotional comprehension decreases in proportion to the perceived severity of reading, although in the emotional test data they have average scores [9].

There are only two studies in which it is possible to relate a specific learning disability to the level of a certain SEC. The longitudinal research talks about cases of dyslexia that improve their SEC levels as they age [3] and the study that observes that the perceived severity of reading can be related to a decrease in self-concept in emotional understanding [9].

The comparison of results between female and male sex is not one of the topics of greatest interest in this review. In those that do analyze it, it can be observed that the percentage of the sample of children and adolescents is higher than that of women $[2,4,5,6,9]$. Likewise, it is recognized that girls and adolescents obtain better scores in competences and social skills, while men have greater problems concerning antisocial behavior $[6,7,9]$. 
Table 1. General descriptive summary

\begin{tabular}{|c|c|c|}
\hline Analyzed Section & Categories & Quantity \\
\hline \multirow{5}{*}{ Objective } & $\begin{array}{l}\text { - Identify the level of socio-emotional competence in boys, girls and / or adolescents } \\
\text { with LD compared to their peers without } \operatorname{LD}[1,2,3,4,5,6,7]\end{array}$ & 7 \\
\hline & $\begin{array}{l}\text { - Identify the level of socio-emotional competence in boys, girls and / or adolescents } \\
\text { with LD compared to their peers with other SEN [8] }\end{array}$ & 1 \\
\hline & $\begin{array}{l}\text { - Identify the level of socio-emotional competencies in boys, girls and / or adolescents } \\
\text { with LD }[9,10]\end{array}$ & 2 \\
\hline & $\begin{array}{l}\text { Investigate a variable associated with a specific socio-emotional competence in boys, } \\
\text { girls and / or adolescents with } \mathrm{LD}[11,12,13,14,15]\end{array}$ & 5 \\
\hline & $\begin{array}{l}\text { - Analyse if the proposed intervention influences the level of a specific socio-emotional } \\
\text { competence in boys, girls and / or adolescents with } \operatorname{LD}[16,17,18,19,20,21]\end{array}$ & 6 \\
\hline \multirow{4}{*}{$\begin{array}{l}\text { Type of approach } \\
\text { and design }\end{array}$} & - Quantitative approach - cross-sectional design $[1,2,4,5,6,7,9,11,13,14,15,17,18$, & 14 \\
\hline & - Quantitative approach - longitudinal design $[3,8,12]$ & 3 \\
\hline & - Qualitative approach - transversal design $[10,16,21]$ & 3 \\
\hline & - $\quad$ Mixed approach - transversal design [19] & 1 \\
\hline \multirow{5}{*}{ Type of sample } & - $\quad$ Boys and girls (4 to 11 years old) $[3,6,8,10,11,16,20]$ & 7 \\
\hline & - $\quad$ Adolescents (12 to 17 years old) $[2,4,5,9,18,19,21]$ & 7 \\
\hline & - Boys, girls and adolescents (4 to 17 years old) $[1,7,13,15,17]$ & 5 \\
\hline & - $\quad$ Adults - young people (18 to 25 years old) [14] & 1 \\
\hline & - $\quad$ Adults - youth and adolescents [12] & 1 \\
\hline \multirow{3}{*}{$\begin{array}{l}\text { Medium for LD } \\
\text { diagnosis }\end{array}$} & - $\quad$ Previous criteria of an expert $[1,4,5,6,7,9,10,13,14,15,17,18,19,20,21]$ & 15 \\
\hline & - Individual educational reports $[2,11,16]$ & 3 \\
\hline & - $\quad$ Specific instruments during the investigation $[3,8,12]$ & 3 \\
\hline \multirow{3}{*}{$\begin{array}{c}\text { Preferred } \\
\text { instruments for } \\
\text { evaluating SEC }\end{array}$} & - $\quad$ The Social Skills Rating System $[7,13,18]$ & 3 \\
\hline & - $\quad$ Social Self-Efficacy Scale $[2,5]$ & 2 \\
\hline & - Children's feelings of loneliness and social dissatisfaction[7, 15] & 2 \\
\hline
\end{tabular}


Table 2. Analysis of results on the relationship between LD and SEC

\begin{tabular}{|c|c|c|c|c|c|}
\hline $\begin{array}{l}\mathbf{N}^{\circ} \\
{[]}\end{array}$ & Bibliography & Sample & Learning Disability & Socio-emotional competence & Results \\
\hline 1 & $\begin{array}{l}\text { Balboni, G., Incognito, O., } \\
\text { Belacchi, C., Bonichini, S., \& } \\
\text { Cubelli, R. (2017). }\end{array}$ & $\begin{array}{l}170 \text { children: } 24 \text { with ADHD ( } 5 \\
\text { - } 14 \text { years), } 61 \text { children with } \\
\text { specific learning disabilities } \\
\text { (6-11 years) and } 85 \text { with typical } \\
\text { development ( } 5 \text { - } 14 \text { years). }\end{array}$ & $\begin{array}{l}\text { General and specific } \\
\text { diagnosis of learning } \\
\text { disabilities in the description } \\
\text { of the sample, but not in the } \\
\text { results }\end{array}$ & $\begin{array}{l}\text { Adaptive behavior: } \\
\text { Communication, socialization } \\
\text { and daily living (adaptive } \\
\text { skills) }\end{array}$ & $\begin{array}{l}\text { Children with SLD obtained significantly lower scores in the } \\
\text { communication subdomains }(\mathrm{t}=5.26 ; \mathrm{p}<.01) \text { : Receptive }(\mathrm{t} \\
=3.15 ; \mathrm{p}<=.01) \text { and written }(\mathrm{t}=6.12 ; \mathrm{p}<.001) \text {, but not } \\
\text { expressive. In addition, they also had low scores in adaptive } \\
\text { behavior composite }(\mathrm{t}=3.56 ; \mathrm{p}<.01)\end{array}$ \\
\hline 2 & $\begin{array}{l}\text { Lorger, T., Schmidt, M., } \\
\text { \&Vukman, K. B. (2015). }\end{array}$ & $\begin{array}{l}417 \text { students. } 85 \text { adolescents } \\
\text { with } L D \text { and } 332 \text { without } L D \\
\quad \text { ( } 15 \text { to } 18 \text { years old) }\end{array}$ & $\begin{array}{l}\text { General diagnosis of learning } \\
\text { disabilities. }\end{array}$ & $\begin{array}{l}\text { Social self-efficacy: make } \\
\text { friends, express opinions, } \\
\text { apologize, resolve conflicts } \\
\text { without violence, talk about } \\
\text { their emotions }\end{array}$ & $\begin{array}{l}\text { Students with } \mathrm{LD} \text { are seen by their peers, more often, as } \\
\text { rejected students. Furthermore, they consider themselves to } \\
\text { be less socially efficient }(\mathrm{t}=-3.97, \mathrm{p}<.001) \text {. }\end{array}$ \\
\hline 3 & $\begin{array}{l}\text { Parhiala, P., Torppa, M., Eklund, } \\
\text { K., Aro, T., Poikkeus, A. M., } \\
\text { Heikkilä, R., \&Ahonen, T. } \\
\text { (2015). }\end{array}$ & $\begin{array}{l}170 \text { children, with reported } \\
\text { ages } 4,6 \text { and } 9.39 \text { diagnosed } \\
\text { with dyslexia and } 131 \text { were a } \\
\text { control group without } \\
\quad \text { difficulties }\end{array}$ & $\begin{array}{l}\text { Specific diagnosis in a } \\
\text { learning area: Dyslexia }\end{array}$ & $\begin{array}{l}\text { Adaptive and social skills, } \\
\text { attention to problems, } \\
\text { externalization and } \\
\text { internalization of problems }\end{array}$ & $\begin{array}{l}\text { Children with dyslexia have significantly more problems } \\
\text { with adaptability and social skills than children without } \\
\text { dyslexia before entering school ( } 4 \text { to } 6 \text { years). However, } \\
\text { there are fewer problems at the age of } 6 \text { to } 9 \text { years }(t=2.06, p \\
<.05) .\end{array}$ \\
\hline 4 & $\begin{array}{l}\text { Schmidt, M., Prah, A., \&Čagran, } \\
\text { B. (2014). }\end{array}$ & $\begin{array}{l}180 \text { adolescents }(12-14 \text { years } \\
\text { old). } 90 \text { students with LD and } \\
90 \text { without LD }\end{array}$ & $\begin{array}{l}\text { Specific diagnosis in a } \\
\text { learning area in the } \\
\text { description of the sample, but } \\
\text { not in the results }\end{array}$ & $\begin{array}{l}\text { Perception of interpersonal } \\
\text { difficulties, apprehension and } \\
\text { fear of negative evaluation, } \\
\text { Tension and Inhibition in Social } \\
\text { Contact, acceptance of oneself }\end{array}$ & $\begin{array}{l}\text { Students with } \mathrm{LD} \text { perceive greater interpersonal difficulties } \\
\text { in the area of public speaking }(\mathrm{t}=2.10, \mathrm{p}<.05) \text {, in } \\
\text { relationships with family }(\mathrm{t}=2.60, \mathrm{p}<.001) \text { and with friends } \\
(3.57, \mathrm{p}<.001) \text {. There are also significant differences that } \\
\text { show that students with } \mathrm{LD} \text { have lower self-concept in the } \\
\text { academic area }(\mathrm{t}=-3.85, \mathrm{p}<.001) \text {, social }(\mathrm{t}=-2.31, \mathrm{p}<.05) \\
\text { and general self-concept }(\mathrm{t}=-2.65, \mathrm{p}<.01)\end{array}$ \\
\hline 5 & $\begin{array}{l}\text { Vukman, K. B., Lorger, T., \& } \\
\text { Schmidt, M. (2018). }\end{array}$ & $\begin{array}{l}417 \text { students. ( } 15 \text { to } 18 \text { years } \\
\text { old). } 105 \text { with } L D \text { and } 312 \\
\text { without } L D\end{array}$ & $\begin{array}{l}\text { General diagnosis of learning } \\
\text { disabilities. }\end{array}$ & $\begin{array}{l}\text { Social self-efficacy, social } \\
\text { anxiety }\end{array}$ & $\begin{array}{l}\text { Students with LD obtain lower scores in social self-efficacy } \\
\text { both at the beginning of the course }(\mathrm{t}=-3.13, \mathrm{p}=.002) \text { and at } \\
\text { the end of it }(\mathrm{t}=-3.97, \mathrm{p}<.001) \text {. They also decreased the } \\
\text { perception of social self-efficacy throughout the course }(\mathrm{t}= \\
2.01, \mathrm{p}<.05) \text {. Likewise, they had higher levels of social } \\
\text { anxiety both at the beginning of the course }(\mathrm{t}=2.00, \mathrm{p}<.05) \text {, } \\
\text { and at the end ( } \mathrm{t}=2.70, \mathrm{p}<0.1) \text {. This anxiety increased } \\
\text { throughout the course, but not significantly. }\end{array}$ \\
\hline 6 & YukayYuksel, M. (2013). & $\begin{array}{c}166 \text { students ( } 7 \text { to } 9 \text { years old), } \\
83 \text { without LD, } 83 \text { diagnosed } \\
\text { with LD }\end{array}$ & $\begin{array}{l}\text { General diagnosis of learning } \\
\text { disabilities. }\end{array}$ & $\begin{array}{c}\text { Social skills: interpersonal, } \\
\text { self-management and academic } \\
\text { skills. }\end{array}$ & $\begin{array}{l}\text { The variable LD does not affect the variable of social } \\
\text { behaviors, nor of antisocial behaviors }\end{array}$ \\
\hline
\end{tabular}


Table 2 Continued Zach, S., Yazdi-Ugav, O.,
\&Zeev, A. (2016).

733 students (6 to 13 years old), 642 without $L D$ and 91 with LD

1835 to 1857 (depending on the output measurements). Period 2004-2012, cohort of children who were 8 or 9 years old in 2012. $\mathrm{LD}=148, \mathrm{SEN}=109$ (2017)

8

Dempsey, I., \& Valentine, M \&Guastaferro, $\mathrm{T}$. (2017).

34 adolescents with specific learning disabilities (14 to 19 years old)

5 directors, 35 teachers, 20 parents and 20 children with LD in the ages of 4-6 years.
Social skills: (cooperation, affirmation, self-control,

General diagnosis of learning disabilities.

responsibility and empathy)
Feelings of loneliness and social dissatisfaction

Subscales: difficulties in

Specific diagnosis in a learning area in the description of the sample, but not in the results relationships with peers, and emotional difficulties, appropriate behavior or prosocial (prosocial skills)

Emotional Intelligence and Emotional Goal: Emotional Beliefs, Self-Concept of

General and specific diagnosis of learning disabilities Emotional Skills and Emotional Skills

General and specific diagnosis of learning disabilities
Students with LD have fewer social skills $(\mathrm{t}=7.58, \mathrm{p}<.001)$, less academic achievement $(\mathrm{t}=13.74, \mathrm{p}<.001)$, more feelings of loneliness $(t=5.25, \mathrm{p}<.001)$, and more behavioral problems $(\mathrm{t}=5.92, \mathrm{p}<.001)$.

Children with LD had higher scores in the prosocial behavior measure compared to the rest of SEN $(t=4.31$, $\mathrm{p}$ $<.001)$.

In the emotional and meta-emotional test, adolescents with SLD present normal ranges, none obtained a score lower than 85. Self-concept of emotional skills increases in proportion to greater difficulties perceived in reading $(r=-$. $465, \mathrm{p}<.01)$. Beliefs and self-concept of emotiona understanding decreased in proportion to the greater perceived severity of reading difficulties $(r=.322, p<.01)$.

According to the teachers' perception, $46.71 \%$ of children with LD do not participate in decisions to carry out activities; $71.43 \%$ are not independent, $62.86 \%$ do not wait their turn or listen to the answers and $48.57 \%$ do not seem to 
Table 3. Associated variables and interventions

\begin{tabular}{|c|c|c|c|c|c|}
\hline $\begin{array}{l}\mathbf{N}^{\circ} \\
{[]}\end{array}$ & Bibliography & Sample & Learning Disability & Socio-emotional competence & Results \\
\hline 11 & $\begin{array}{l}\text { Brooks, B. A., Floyd, F., } \\
\text { Robins, D. L., \& Chan, W. } \\
\text { Y. (2015). }\end{array}$ & $\begin{array}{l}117 \text { children ( } 8 \text { to } 11 \\
\text { years old). } 40 \text { children } \\
\text { with intellectual } \\
\text { disabilities, } 53 \text { with } \\
\text { learning disabilities and } \\
24 \text { with typical } \\
\text { development }\end{array}$ & $\begin{array}{l}\text { General diagnosis of } \\
\text { learning disabilities. }\end{array}$ & $\begin{array}{l}\text { Behavior in } 7 \text { social tasks: Joining groups, } \\
\text { responding to others, managing disagreements, } \\
\text { helping others, playing games, having } \\
\text { conversations, and handle teasing. Adaptive } \\
\text { behavior: Language, vocational and domestic } \\
\text { activities, and social behavior. }\end{array}$ & $\begin{array}{l}\text { Students with LD had no significant differences in social } \\
\text { competencies compared to typically developed children. } \\
\text { A high participation in unstructured extracurricular } \\
\text { activities predicts better social skills }(\beta=0.23, p<.05 \text { ). }\end{array}$ \\
\hline 12 & $\begin{array}{c}\text { Hakkarainen, A. M., } \\
\text { Holopainen, L. K., \& } \\
\text { Savolainen, H. K. (2016). }\end{array}$ & $\begin{array}{l}597 \text { adolescents, } 304 \\
\text { women and } 293 \text { men }(\mathrm{M} \\
\text { age } 15.9 \text { in } 2004) .21 \\
\text { years }\end{array}$ & $\begin{array}{l}\text { Specific diagnosis in a } \\
\text { learning area }\end{array}$ & $\begin{array}{l}\text { Social competence (cooperation skills, empathy, } \\
\text { impulsivity, disruptive behaviors): prosocial } \\
\text { dimension - antisocial behavior }\end{array}$ & $\begin{array}{l}\text { There is no significant correlation between diff. in math } \\
\text { and reading with low prosocial skills. Commitment to } \\
\text { continuing training or employment processes at age } 21 \text { is } \\
\text { related to dif. in reading (rho }=0.14, \mathrm{p}<.05 \text { ) and } \\
\text { socio-emotional problems ( }(\mathrm{rho}=0.20, \mathrm{p}<.01 \text { ) in high } \\
\text { school. The delay in graduation from compulsory studies } \\
\text { was related to dif. in mathematics ( } \mathrm{rho}=0.13, \mathrm{p}<.05 \text { ) }\end{array}$ \\
\hline 13 & $\begin{array}{l}\text { Helton, J. J., Gochez-Kerr, } \\
\text { T., \& Gruber, E. (2017). }\end{array}$ & $\begin{array}{l}2,033 \text { cases. } 4 \text { to } 17.5 \\
\text { years. From } 83 \text { US } \\
\text { counties. Children and } \\
\text { adolescents with and } \\
\text { without LD }\end{array}$ & $\begin{array}{l}\text { General diagnosis of } \\
\text { learning disabilities. }\end{array}$ & $\begin{array}{l}\text { Social skills, social dissatisfaction and feeling of } \\
\text { loneliness }\end{array}$ & $\begin{array}{l}\mathrm{LDs} \text { are associated with higher risks of sexual abuse and } \\
\text { more cases of sexual abuse. There is a higher percentage } \\
\text { of children with } \mathrm{LD} \text { who have been victims of sexual } \\
\text { abuse }(21 \% \text { vs. } 10 \% \text {; chi square }=7.74 ; \mathrm{p}<.01) \text {. Children } \\
\text { with } \mathrm{LD} \text { have greater comorbid conditions: internalizing } \\
(\mathrm{t}=1.35, \mathrm{p}<.01) \text { and externalizing }(\mathrm{t}=2.00, \mathrm{p}<.01) \\
\text { behavior problems; less functionality in daily living ( } \mathrm{t}= \\
2.42, \mathrm{p}<.01) \text {; poor social skills }(\mathrm{t}=2.83, \mathrm{p}<.01) \text { and } \\
\text { increasing feelings of loneliness }(\mathrm{t}=2.94, \mathrm{p}<.01) \text {. }\end{array}$ \\
\hline 14 & $\begin{array}{l}\text { Hen, M., \&Goroshit, M. } \\
\text { (2014). }\end{array}$ & $\begin{array}{l}287 \text { undergraduate } \\
\text { sophomores ( } 25 \text { years), } \\
99 \text { with LD and } 188 \\
\text { without LD }\end{array}$ & $\begin{array}{l}\text { General diagnosis of } \\
\text { learning disabilities. }\end{array}$ & $\begin{array}{c}\text { Emotional intelligence: evaluation and expression } \\
\text { of emotions, regulation of emotions, use of } \\
\text { emotions }\end{array}$ & $\begin{array}{l}\text { Differences were found between students with } \mathrm{LD} \text { and } \\
\text { their peers without } \mathrm{LD}=7.83, \mathrm{p}<.001 ; \eta 2=.077 \text {. } \\
\text { Students with } \mathrm{LD} \text { have lower scores in emotional } \\
\text { intelligence and emotional self-efficacy and higher rates } \\
\text { of academic procrastination }\end{array}$ \\
\hline 15 & $\begin{array}{l}\text { Yılmaz, A., Kırımoğlu, H., } \\
\text { \&Soyer, F. (2018). }\end{array}$ & $\begin{array}{c}56 \text { boys, girls and } \\
\text { adolescents ( } 7 \text { and } 14 \\
\text { years old) diagnosed } \\
\text { with AD. } 30 \text { boys and } 26 \\
\text { girls }\end{array}$ & $\begin{array}{l}\text { General diagnosis of } \\
\text { learning disabilities. }\end{array}$ & $\begin{array}{l}\text { Feeling of loneliness, Social Skills (Aggression / } \\
\text { Antisocial Behavior, Social Skills / Assertiveness) }\end{array}$ & $\begin{array}{l}\text { Sports have a positive role in social skills. In children } \\
\text { with } \mathrm{LD} \text { there is a significant negative correlation in } \\
\text { assertiveness and aggressiveness }(\mathrm{r}=-.61, \mathrm{p}<0.001) \text {, and } \\
\text { a positive and significant correlation between } \\
\text { aggressiveness and loneliness scale }(\mathrm{r}=.39, \mathrm{p}<.01)\end{array}$ \\
\hline 16 & Anderson, A. (2015, July). & $\begin{array}{l}14 \text { seventh grade } \\
\text { students from an urban } \\
\text { public school. }\end{array}$ & $\begin{array}{l}\text { General diagnosis of } \\
\text { learning disabilities. }\end{array}$ & $\begin{array}{l}\text { Self-control of behavior, self-regulation of } \\
\text { abilities, taking responsibility for their behavior, } \\
\text { expressing emotions appropriately, awareness of } \\
\text { the personal space of others }\end{array}$ & $\begin{array}{l}\text { The students who took part in the intervention program } \\
\text { established for } 1 \text { month, showed an improvement in their } \\
\text { performance in mathematics, dance, and in } \\
\text { social-emotional dimensions such as: motivation, } \\
\text { commitment, self-esteem and self-regulation }\end{array}$ \\
\hline
\end{tabular}


Table 3 Continued

\begin{tabular}{|c|c|c|c|c|c|}
\hline 17 & $\begin{array}{l}\text { Bhan, S., \& Farooqui, Z. } \\
\text { (2013). }\end{array}$ & $\begin{array}{l}30 \text { students with learning } \\
\text { disabilities ( } 9-12 \text { years } \\
\text { old), } 15 \text { from the } \\
\text { experimental group and } \\
15 \text { from the control } \\
\text { group }\end{array}$ & $\begin{array}{l}\text { General diagnosis of } \\
\text { learning disabilities. }\end{array}$ & $\begin{array}{c}\text { Recognition of six basic emotions, own and of } \\
\text { others. }\end{array}$ & $\begin{array}{l}\text { The intervention program with students with } L D \text { from the } \\
\text { experimental group improved the identification of } \\
\text { emotions in pictorial representations }(\mathrm{t}=-18.09, \mathrm{p}<.001) \\
\text { and verbal }(\mathrm{t}=-16.72, \mathrm{p}<.001) \text { and also the expression of } \\
\text { emotions in a socially appropriate way }(\mathrm{t}=-8.940, \mathrm{p} \\
<.001) .\end{array}$ \\
\hline 18 & $\begin{array}{l}\text { Greenbank, A., \& Sharon, } \\
\text { A. (2013). }\end{array}$ & $\begin{array}{c}77 \text { students with LD. In } \\
\text { grades } 7 \text { to } 10(12-17 \\
\text { years), experimental } \\
\text { group } 43 \text { and control } \\
\text { group } 34.39 \text { with } \\
\text { borderline IQ and } 38 \\
\text { normal IQ }\end{array}$ & $\begin{array}{l}\text { General diagnosis of } \\
\text { learning disabilities. }\end{array}$ & $\begin{array}{l}\text { Recognition of non-verbal emotional messages, } \\
\text { social skills (empathy, cooperation and } \\
\text { self-control) social approach. }\end{array}$ & $\begin{array}{l}\text { The intervention improves the recognition of facial } \\
\text { expressions }(\mathrm{t}=11.25, \mathrm{p}<.001) \text { and body language }(\mathrm{t}= \\
6.01, \mathrm{p}<.001) \text {. However, no significant effects were } \\
\text { found on social skills. }\end{array}$ \\
\hline 19 & $\begin{array}{l}\text { Louis, P. T., \& Emerson, I. } \\
\text { A. (2014). }\end{array}$ & $\begin{array}{l}\text { 13-year-old adolescent } \\
\text { with LD }\end{array}$ & $\begin{array}{l}\text { Specific diagnosis in a } \\
\text { learning area }\end{array}$ & $\begin{array}{l}\text { Social skills: General self-help, locomotion, } \\
\text { occupation, communication and socialization. }\end{array}$ & $\begin{array}{l}\text { The intervention had a positive impact by increasing the } \\
\text { social age by one year (Pre-intervention Social } \\
\text { Coefficient }=84 \text {, Post-intervention Social Coefficient }= \\
88 \text { ) }\end{array}$ \\
\hline 20 & $\begin{array}{l}\text { Noushabadi, F. R., } \\
\text { Adibsereshki, N., Sajedi, F., } \\
\text { Bakhshi, E., Rostami, M., } \\
\text { \&Syakhaneh, S. (2015). }\end{array}$ & $\begin{array}{l}40 \text { male students } \\
\text { diagnosed with LD ( } 20 \\
\text { control group - } 20 \\
\text { experimental). 3rd to } 5 \text { th } \\
\text { grade }\end{array}$ & $\begin{array}{l}\text { General diagnosis of } \\
\text { learning disabilities. }\end{array}$ & $\begin{array}{l}\text { Cognitive skills, Behavioral skills, emotional } \\
\text { competence, set of motivations and expectations }\end{array}$ & $\begin{array}{l}\text { The intervention had a positive impact on the behavioral, } \\
\text { cognitive, emotional, motivational and social skills ( } \mathrm{p} \\
<.01 \text { ) of children with LD with previous problems in } \\
\text { these areas. }\end{array}$ \\
\hline 21 & $\begin{array}{l}\text { White, J., Caniglia, C., } \\
\text { McLaughlin, T. F., \& } \\
\text { Bianco, L. (2018). }\end{array}$ & $\begin{array}{l}\text { 13-year-old adolescent } \\
\text { with LD }\end{array}$ & $\begin{array}{l}\text { Specific diagnosis in a } \\
\text { learning area }\end{array}$ & $\begin{array}{l}\text { Previous diagnosis: Deficiency in communication, } \\
\text { behavior and social skills Diagnosis during the } \\
\text { research: inappropriate relationships with their } \\
\text { peers }\end{array}$ & $\begin{array}{l}\text { During the first intervention he had } 5.4 \text { inappropriate } \\
\text { behaviors with his peers, at the beginning of session } 8 \text { the } \\
\text { number of inappropriate behaviors decreased to } 1 \text {. At the } \\
\text { end of the intervention the number decreased to } 0 \text {. The } \\
\text { intervention program was satisfactory }\end{array}$ \\
\hline
\end{tabular}


Associated consequences in the relationship between LDs and SECs (Table 3)

In the search for articles, it was possible to identify that several studies start from the certainty that boys, girls, and/or adolescents with LD have low levels of SEC; therefore, they aim to identify what additional consequences could be triggered from these deficits.

In the examined articles, three specific consequences were found: Young people with a diagnosis of LD and with socio-emotional problems have delays in graduating from high school, difficulties in finding a job, and little commitment to education [12]; children with LD, with behavioral problems, low social skills, and feelings of loneliness, are prone to sexual abuse [13]; students with LD and a lower score on the emotional intelligence test are more prone to academic procrastination [14].

Recommended interventions to increase SEC in boys, girls, and/or adolescents with LD (Table 3)

Some studies suggest intervention proposals with different methodologies in which, all except for one, are successful in increasing the SEC of boys, girls, and/or adolescents with LD. It was determined that children with LD who are exposed to unstructured extracurricular activities (free games) have better SEC [11], however, it was also possible to visualize that sports play a positive role for the growth of social skills and the decrease of feelings of loneliness [15].

Intervention programs are also proposed for emotional self-regulation and identification of the emotions to achieve higher empathy and better socialization $[17,19,20$, 21]. It was also found that a systematized dance program improves performance in mathematics and skills such as motivation, commitment, self-esteem, and self-regulation of emotions to take responsibility for their behavior and awareness of the personal space of the other [16]. Conversely, the study that was not successful in the application of the intervention in the improvement of social skills obtained positive results in increasing the recognition of facial expressions and body language [18].

\section{Discussion and Conclusions}

The relationship of LD and SEC has been studied in previous decades [32,35], findings ensure that children and adolescents with LD have problems with assertive manifestation, however, there is a small number of publications that address this issue from current contexts and with more specific explanations of the reason for this relationship.

The researches in this review also agree that students with LD have lower SEC than students without LD, but two studies disagree with this conclusion, ensuring that they have equal levels of SEC. In this sense, it could be observed that there are some limitations in the researches, such as the diversity of instruments applied, the variety of types of SEC, and the lack of specificity of LDs, which make it difficult to draw definitive conclusions about the influence that one of these variables exerts on the other or the difficulty of finding differential profiles at the SEC level depending on the LD subtype. There are also no contributions focusing on the causes of a lower level of SEC in boys, girls, and adolescents with LD, which raises the questions of which of the two difficulties arises first, or if the two appear at the same time; or if there is a third intervening variable for this relationship, such as lower metacognitive skills, self-regulation, low self-esteem indices, the type of $\mathrm{LD}$, among others.

Another aspect that is not clear is how the sex of the research subjects affects the relationship between the variables. Studies are required to analyze whether the biological conditions of each sex, or the cultural impositions of gender, develop or limit certain types of SEC or LD, and how they affect the relationship of these two. The results found in this review show a higher prevalence of LD in male children and adolescents, but they do not allow the identification of the most affected areas in each sex, as other researches do in which it is ensured that children have additional deficits in reading and spelling and women have more deterioration in math skills [26]. SEC also need to be studied more specifically in each sex, since the studies in this review affirm that women have better social skills, while men show difficulties externalizing social behaviors, however, other studies assure they do not have found differences between the SEC of boys and girls [9].

Longitudinal researches could discover if there is some type of causal relationship and how the coexistence of LDs and SSCs evolves; however, in the longitudinal researches of this review, there are methodological limitations that affect the deepening of this analysis. Only one of the longitudinal researches indicates that SEC problems in children decrease with age, therefore, more researches of this type would be necessary to address this evolution, and the reasons underlying it.

Studies have analyzed the impact of the SEC low level in children and adolescents with LD point out that these can trigger different difficulties in academic achievement, job placement, lower social skills, behavior problems, and more likely to be sexually abused $[16,18,23]$. However, it is not clear which part of such difficulties would derive from LDs and which, from SECs, or even if when LD and SEC are presented together they are more serious. It could also be observed that the interest in reducing these difficulties has prompted the proposal of some intervention programs to increase and balance the SEC of this population $[3,6,15,23,27,37]$.

Finally, the importance of having good SEC management lies in the fact that the good development of these competencies could allow the reduction of the daily problems that can be presented to people with LD. For this 
reason, it is important to continue with more specific studies in this area to find ways for this population group to have better opportunities for their academic, social, and labor insertion.

\section{REFERENCES}

References marked with * indicate the studies included in the systematic review.

[1] Al-Dababneh, K. A., \& Al-Zboon, E. K. (2018). Understanding Impulsivity Among Children with Specific Learning Disabilities in Inclusion Schools. Learning Disability Quarterly, 41(2), 100-112.https://doi.org/10.1177 /0731948717726497

[2] APA (2013). Diagnostic and Statistical Manual of Mental Disorders (DSM-V) (Fifth Edition). Washington, DC: American Psychiatric Association.

[3] *Anderson, A. (2015, July). Dance/Movement Therapy's Influence on Adolescents' Mathematics, Social-Emotional, and Dance Skills. In the Educational Forum (Vol. 79, No. 3, pp. 230-247). Routledge. https://doi.org/10.1080/00131725. 2015.1037512

[4] Aro, T., Eklund, K., Eloranta, A. K., Närhi, V., Korhonen, E., \& Ahonen, T. (2019). Associations between childhood learning disabilities and adult-age mental health problems, lack of education, and unemployment. Journal of learning disabilities, 52(1), 71-83. https://doi.org/10.1177/00222194 18775118

[5] *Balboni, G., Incognito, O., Belacchi, C., Bonichini, S., \&Cubelli, R. (2017). Vineland-II adaptive behavior profile of children with attention-deficit/hyperactivity disorder or specific learning disorders. Research in developmental disabilities, 61, 55-65. https://doi.org/10.1016/j.ridd.2016.1 2.003

[6] *Bhan, S., \& Farooqui, Z. (2013). Social Skills Training of Children with Learning Disability. Disability, $C B R$ \&Inclusive Development, 24(2), 54-63.https://doi.org/10.54 63/dcid.v24i2.216

[7] BisquerraAlzina, R. (2003). Educación emocional y competencias básicas para la vida [Emotional education and basic competences for life]. Revista de Investigación Educativa (RIE), 21(1), 7-43.

[8] *Brooks, B. A., Floyd, F., Robins, D. L., \& Chan, W. Y. (2015). Extracurricular activities and the development of social skills in children with intellectual and specific learning disabilities. Journal of Intellectual Disability Research, 59(7), 678-687. https://doi.org/10.1111/jir.12171

[9] Chen, X., Chang, L., Liu, H., \& He, Y. (2008). Effects of the peer group on the development of social functioning and academic achievement: A longitudinal study in Chinese children. Child development, 79(2), 235-251.https://doi.org /10.1111/j.1467-8624.2007.01123.x

[10] Daley, S., \& Rappolt-Schlichtmann, G. (2018). Stigma Consciousness Among Adolescents with Learning Disabilities: Considering Individual Experiences of Being
Stereotyped. Learning Disability Quarterly, Vol. 41 Issue 4, p200-212. 13p. DOI: 10.1177/0731948718785565. https://d oi.org/10.1177/0731948718785565

[11] *D'Amico, A., \& Guastaferro, T. (2017). Emotional and Meta-Emotional Intelligence as Predictors of Adjustment Problems in Students with Specific Learning Disorders. International Journal of Emotional Education, 9(2), 17-30.

[12] *Dempsey, I., \& Valentine, M. (2017). Special Education Outcomes and Young Australian School Students: A Propensity Score Analysis Replication. Australasian Journal of Special Education, 41(1), 68-86. https://doi.org/ $10.1017 /$ jse. 2017.1

[13] Frederickson, N., \& Reason, R. (1995). Discrepancy definitions of specific learning difficulties. Educational Psychology in Practice, 10(4), 195-205. https://doi.org/10.1 080/0266736950100401

[14] Goleman, D. (1995). Inteligencia emocional. Editorial Kairós. Barcelona

[15] *Greenbank, A., \& Sharon, A. (2013). Recognizing non-verbal social cues promotes social performance in LD adolescents. Alberta Journal of Educational Research, 59(2), 266-284.

[16] *Hakkarainen, A. M., Holopainen, L. K., \& Savolainen, H. K. (2016). The impact of learning difficulties and socioemotional and behavioural problems on transition to postsecondary education or work life in Finland: a five-year follow-up study. European Journal of Special Needs Education, 31(2), 171-186. https://doi.org/10.1080/0885625 7.2015.1125688

[17] Hazel, J. S., \& Schumaker, J. B. (1988). Social skills and learning disabilities: Current issues and recommendations for future research. In Learning disabilities: Proceedings of the national conference (pp. 293-344). Parkton, MD: York Press.

[18] *Helton, J. J., Gochez-Kerr, T., \& Gruber, E. (2018). Sexual abuse of children with learning disabilities. Child maltreatment, 23(2), 157-165. https://doi.org/10.1177/1077 559517733814

[19] *Hen, M., \&Goroshit, M. (2014). Academic procrastination, emotional intelligence, academic self-efficacy, and GPA: A comparison between students with and without learning disabilities. Journal of learning disabilities, 47(2), 116-124. https://doi.org/10.1177/0022219412439325

[20] *Lilian, G. K., Odundo, P. A., \&Ngaruiya, B. (2015). Effects of Emotional Needs on Participation of Children Aged 4-6 with Learning Disabilities in Early Childhood Centers in Starehe Division, Nairobi County, Kenya. World Journal of Education, 5(3), 79-90. https://doi.org/10.5430/ wje.v5n3p79

[21] Linares-Espinós, E., Hernández, V., Domínguez-Escrig, J., Fernández-Pello, S., Hevia, V., Mayor, J., Padilla-Fernández, B. \&Ribal, M. (2018). Metodología de una revision sistemática. Actas Urológicas Españolas, 42(8), 499-506. https://doi.org/10.1016/j.acuro.2018.01.010

[22] *Lorger, T., Schmidt, M., \&Vukman, K. B. (2015). The social acceptance of secondary school students with learning disabilities (LD). Center for Educational Policy Studies Journal, 5(2), 177-194. 
[23] *Louis, P. T., \& Emerson, I. A. (2014). Evaluating the cognition, behavior, and social profile of an adolescent with learning disabilities and assessing the effectiveness of an individualized educational program. Iranian journal of psychiatry and behavioral sciences, 8(2), 22.

[24] Mayer, J. D. y Salovey, P. (1997). What Is Emotional Intelligence?. (3-31). En Salovey, P. y Sluyter, D. J. (1997): Emotional development and emotional intelligence. New York: BasicBooks. https://doi.org/10.1037/t05047-000

[25] Milligan, K., Phillips, M., \& Morgan, A. S. (2016). Tailoring social competence interventions for children with learning disabilities. Journal of Child and Family Studies, 25(3), 856-869. https://doi.org/10.1007/s10826-015-0278-4

[26] Moll, K., Kunze, S., Neuhoff, N., Bruder, J., \& Schulte-Körne, G. (2014). Specific learning disorder: prevalence and gender differences. PLoS one, 9(7), e103537. https://doi.org/10.1371/journal.pone.0103537

[27] *Noushabadi, F. R., Adibsereshki, N., Sajedi, F., Bakhshi, E., Rostami, M., \& Syakhaneh, S. (2015). Social Competence of Students with Learning Disability: Advantages of Verbal Self-Instructional Package. Iranian Rehabilitation Journal, 13(1), 8-13.

[28] Nowicki, E. A., Brown, J. D., \& Dare, L. (2018). Educators' evaluations of children's ideas on the social exclusion of classmates with intellectual and learning disabilities. Journal of Applied Research in Intellectual Disabilities, 31(1), e154-e163. https://doi.org/10.1111/jar.12356

[29] *Parhiala, P., Torppa, M., Eklund, K., Aro, T., Poikkeus, A. M., Heikkilä, R., \&Ahonen, T. (2015). Psychosocial functioning of children with and without dyslexia: A follow - up study from ages four to nine. Dyslexia, 21(3), 197-211. https://doi.org/10.1002/dys.1486

[30] Perestelo-Pérez, L. (2013). Standards on how to develop and report systematic reviews in Psychology and Health. International Journal of Clinical and Health Psychology, 13(1), 49-57. https://doi.org/10.1016/s1697-2600(13)70007 $-3$

[31] Repetto, E. y Pérez, J. C. (2003). Orientación y Desarrollo de los Recursos Humanos en la pequeña y medianaempresa. Madrid: UNED

[32] Rourke, BP (1988). Trastornos socioemocionales del aprendizaje de niñosdiscapacitados. Revista de Psicología Clínica y Consultoría ,56 (6), 801.

[33] *Schmidt, M., Prah, A., \& Čagran, B. (2014). Social skills of Slovenian primary school students with learning disabilities. Educational Studies, 40(4), 407-422. https://doi.org/10.108 $0 / 03055698.2014 .930339$

[34] Swanson, H. L., \& Malone, S. (1992). Social skills and learning disabilities: A meta-analysis of the literature. School Psychology Review.

[35] Vaughn, S., \& Haager, D. (1994). Social competence as a multifaceted construct: How do students with learning disabilities fare?.Learning Disability Quarterly, 17(4), 253-266. https://doi.org/10.2307/1511123

[36] *Vukman, K. B., Lorger, T., \& Schmidt, M. (2018). Perceived self-efficacy and social anxiety changes in high school students with learning disabilities (LD) during first year of secondary vocational education. European Journal of Special Needs Education, 33(4), 584-594. https://doi.org/ $10.1080 / 08856257.2017 .1410320$

[37] *White, J., Caniglia, C., McLaughlin, T. F., \& Bianco, L. (2018). The Effects of Social Stories and a Token Economy on Decreasing Inappropriate Peer Interactions with a Middle School Student. Learning Disabilities: A Contemporary Journal, 16(1), 75-86.

[38] *Yılmaz, A., Kırımoğlu, H., \&Soyer, F. (2018). Comparison of Loneliness and Social Skill Levels of Children with Specific Learning Disabilities in Terms of Participation in Sports. Education Sciences, 8(1), 37. https://doi.org/10.339 0/educsci8010037

[39] *YukayYuksel, M. (2013). An Investigation of Social Behaviors of Primary School Children in terms of Their Grade, Learning Disability and Intelligence Potential. Educational Sciences: Theory and Practice, 13(2), 781-793.

[40] *Zach, S., Yazdi-Ugav, O., \&Zeev, A. (2016). Academic achievements, behavioral problems, and loneliness as predictors of social skills among students with and without learning disorders. School Psychology International, 37(4), 378-396. https://doi.org/10.1177/0143034316649231

[41] Zysberg, L., \&Kasler, J. (2017). Learning Disabilities and Emotional Intelligence. The Journal of psychology, 151(5), 464-476. https://doi.org/10.1080/00223980.2017.1314929 